\title{
EFEKTIVITAS SIMULASI PELATIHAN BANTUAN HIDUP DASAR (BHD) TERHADAP PENINGKATAN PENGETAHUAN DAN MOTIVASI TENTANG PENANGANAN KEJADIAN KECELAKAAN LALU LINTAS (KLL) PADA TUKANG OJEK
}

\author{
Djunizar Djamaludin ${ }^{1}$, Eka Yudha Chrisanto ${ }^{2 *}$, Lisa Yuliana Sari ${ }^{3}$
}

1Dosen Program Studi Ilmu Keperawatan Universitas Malahayati

E-mail : djunizar@malahayati.ac.id

2Dosen Program Studi Ilmu Keperawatan Universitas Malahayati

E-mail : yudhachrisanto88@gmail.com

${ }^{3}$ Mahasiswi Program Studi Ilmu Keperawatan Universitas Malahayati

E-mail : lisayuliana708@gmail.com

\section{ABSTRACT: THE EFFECTIVENESS OF BASIC LIFE SUPPORT (BLS) TRAINING ON INCREASING KNOWLEDGE AND MOTIVATION OF TRAFFIC ACCIDENTS HANDLING IN MOTORCYCLE TAXI DRIVERS}

Introduction: Motorcycle taxi drivers are travelers who are often exposed to traffic accidents, where many motorcycle taxi drivers do activities on the streets such as waiting for orders, receiving orders and placing orders. Online motorcycle taxi providers moreover never provided basic life support training for online motorcycle taxi drivers. Factors of work accidents, work fatigue, poor sleep quality and the behavior of motorcycle taxi drivers that cause traffic accidents.

Purpose: This study to determine the effectiveness of the basic life support (BLS) training on increasing knowledge and motivation traffic accidents handling in motorcycle taxi drivers at Bumisari Village, Natar District in 2021.

Method: This study used a quasy experimental method of pre and post design. The subject of the research were the motorcycle drivers in the city of Natar, Lampung Selatan both the motorcycle driver's base and the online motorcycle drivers. Total 30 participants were requireted with purposive sampling. This research was using knowledge and motivaton questionnairs. Analysis bivariate were tested using paired $t$ test and independent $t$-test using $t$-dependent test. Result: The average knowledge and motivation before being given a simulation of basic life support training (BLS) on handling traffic accidents on motorcycle taxi drivers, the mean of knowledge is 4.13 and the mean of motivation is 30.67 . While online motorcycle taxi drivers have an average value before being given a BLS training simulation, namely the mean knowledge of 3.93 and the mean motivation of 29.40. The average knowledge and motivation after being given a simulation of basic life support (BLS) training on handling traffic accidents on motorcycle taxi drivers, the mean of knowledge is 8.93 and the mean of motivation is 60.00. Meanwhile, online motorcycle taxi drivers have an average value after being given a BLS training simulation, namely the mean knowledge is 8.73 and the mean motivation is 66.53. The results of bivariate data analysis using the t-test dependent test obtained $p$-value $0.000<0.05$, it can be concluded that there is an effectiveness of basic life support training (BLS) simulation on increasing knowledge and motivation about handling traffic accidents (KLL) in motorcycle taxi drivers in Bumisari Village, Natar District in 2021 
Conclusion: It is hoped that there will be increased learning about health promotion methods regarding basic life support (BHD) targeted at the community, especially motorcycle taxi drivers in Bumisari Village, Natar District.

Keywords $\quad$ : Basic Life Support (BLS) Simulation, Knowledge, Motivation

\section{INTISARI: EFEKTIVITAS PELATIHAN BANTUAN HIDUP DASAR (BHD) TERHADAP PENINGKATAN PENGETAHUAN DAN MOTIVASI PENANGANAN KECELAKAAN LALU LINTAS PADA PENGEMUDI TAKSI SEPEDA MOTOR}

Latar Belakang: Tukang ojek merupakan pelaku perjalanan yang sering terpapar dengan kecelakaan lalu lintas, dimana aktifitas tukang ojek banyak dilakukan dijalanan seperti menunggu orderan, menerima orderan dan melakukan orderan. Provider ojek online juga tidak pernah menyediakan pelatihan pertolongan pertama pada kecelakaan pada pengemudi ojek online. Faktor kecelakaan kerja, kelelahan kerja, kualitas tidur yang buruk dan perilaku tukang ojek berakibat terjadinya kecelakaan lalu lintas.

Tujuan: Diketahuinya efektivitas pelatihan bantuan hidup dasar (BHD) terhadap peningkatan pengetahuan dan motivasi tentang penanganan kejadian kecelakaan lalu lintas (KLL) pada tukang ojek di Desa Bumisari Kecamatan Natar Tahun 2021. Metode Penelitian: Penelitian ini menggunakan metode quasi eksperimental dengan pre and post design. Subyek penelitian ini adalah para tukang ojek di Kota Natar, Lampung Selatan baik tukang ojek pangkalan maupun ojek online. Jumlah tukang ojek yang bersedia mengikuti penelitian yaitu sebanyak 30 orang dengan purposive sampling. Penelitian ini menggunakan kuesioner pengetahuan dan motivasi. Analisis bivariat diuji dengan menggunakan uji t berpasangan dan uji t independen

Hasil : Rata-rata pengetahuan dan motivasi sebelum diberi simulasi pelatihan bantuan hidup dasar (BHD) tentang penanganan kejadian kecelakaan lalu lintas (KLL) pada tukang ojek pangkalan mean pengetahuan 4,13 dan mean motivasi 30,67 . Sedangkan pada tukang ojek online terdapat nilai rata-rata sebelum diberi simulasi pelatihan BHD yaitu mean pengetahuan 3,93 dan mean motivasi 29,40 Rata-rata pengetahuan dan motivasi sesudah diberi simulasi pelatihan bantuan hidup dasar (BHD) tentang penanganan kejadian kecelakaan lalu lintas (KLL) pada tukang ojek pangkalan mean pengetahuan 8,93 dan mean motivasi 60,00. Sedangkan pada tukang ojek online terdapat nilai rata-rata sesudah diberikan simulasi pelatihan BHD yaitu mean pengetahuan 8,73 dan mean motivasi 66,53. Hasil analisa data bivariat menggunakan uji dependen $t$-tes didapat nilai $p$-value $0,000<0,05$ maka dapat ditarik kesimpulan bahwa terdapat efektivitas simulasi pelatihan bantuan hidup dasar (BHD) terhadap peningkatan pengetahuan dan motivasi tentang penanganan kejadian kecelakaan lalu lintas (KLL) pada tukang ojek di Desa Bumisari Kecamatan Natar Tahun 2021.

Kesimpulan: Diharapkan dapat mengadakan peningkatan pembelajaran tentang metode promosi kesehatan mengenai bantuan hidup dasar (BHD) yang ditargetkan kepada masyarakat khususnya Tukang Ojek di Desa Bumisari Kecamatan Natar.

Kata Kunci: Simulasi Bantuan Hidup Dasar (BHD), Pengetahuan, Motivasi 


\section{PENDAHULUAN}

Sejalan dengan penelitian yang dilakukan oleh Yenny (2017) FaktorFaktor Yang Berhubungan Dengan Penanganan Bantuan Hidup Dasar (Basic Life Support) Pada Kajadian Kecelakaan Lalu Lintas. Pertumbuhan penduduk tidak selalu berdampak positif bagi pembangunan manusia. Pertambahan jumlah penduduk seringkali disertai dengan peningkatan masalah kehidupan, khususnya di bidang kesehatan masyarakat. Salah satu masalah utama di bidang kesehatan masyarakat adalah tingginya angka kecelakaan lalu lintas. Selain menjadi penyebab kematian utama di dunia, kecelakaan lalu lintas juga menjadi salah satu penyebab kematian paling umum di antara cedera akibat kecelakaan lainnya, seperti jatuh. Situasi ini merupakan tantangan besar bagi tujuan pembangunan berkelanjutan yang diusulkan dalam Tujuan Pembangunan Berkelanjutan (SDGs) 2030, yang mengusulkan tujuan untuk mengurangi tingkat kematian kecelakaan lalu lintas global sebesar 50\% pada tahun 2020 (United Station, 2019; Syahriza, 2019). Sejalan dengan penelitian

Pemerintah kabupaten/kota Lampung Selatan sendiri, memperoleh data dari jumlah kecelakaan pada tahun 2019 mencapai 343. Sebanyak 133 orang meninggal dunia (MD), 234 orang luka berat (LB), dan luka ringan 289 orang (LR). Sedangkan kerugian kematian (Rugmat) dalam satu tahun mencapai 35.865,5 juta rupiah. Tingkat kecelakaan tertinggi terjadi pada Juni 2019, mencapai 47. Jumlah korban adalah 14 MD, 34 LB, dan 71 LR. (Jasa Raharja, 2019).

Data korban kecelakaan lalu lintas di Kabupaten Lampung Selatan, didapat jumlah sebanyak 294, dengn keterangan korban meninggal dunia sebanyak 101 orang, korban luka berat 257, korban luka ringan 212 orang. Sedangkan berdasarkan dari usia korban 0-9 tahun sebanyak 16 orang, usia 10-15 sebanyak 37 orang, usia 16-30 tahun sebanyak 237 orang, usia 31-40 tahun 141 orang, usia 41-50 tahun sebanyak 56 orang, usia 51 tahun keatas 53 orang (Kepolisian Resor Lampung Selatan, 2020).

Pengemudi ojek merupakan pemudik yang sering mengalami kecelakaan lalu lintas, banyak pengemudi ojek yang menunggu mobil, menerima pesanan, dan memesan di jalan. Penyedia ojek online belum pernah memberikan pelatihan pertolongan pertama kecelakaan bagi pengemudi ojek online (Rahmadita, 2018). Hasil penelitian yang dilakukan oleh Tanriono, Doda \& Manampiring (2019). Menunjukkan bahwa faktor kecelakaan kerja, kelelahan kerja, kualitas tidur yang buruk dan perilaku tukang ojek berakibat terjadinya kecelakaan lalu lintas.

Tukang ojek pangkalan maupun ojek online di Desa Bumisari merupakan orang yang lebih sering menemukan terjadinya kecelakaan sehingga perlu dilakukannya pelatihan dengan tujuan mengasah skill para ojek untuk melakukan pertolongan pertama saat terjadi kecelakaan dengan baik.

Data prasurvey yang dilakukan pada tanggal 17 Maret 2021 untuk mengetahui jumlah ojek online dan ojek pangkalan di Kecamatan Natar, didadapat 178 orang ojek, dengan pembagian 163 orang merupakan ojek online dan 15 orang merupakan ojek pangkalan. Selanjutnya dilakukan wawancara bebas terpimpin terhadap 6 orang ojek yang sedang beristirahat terkait bantuan hidup dasar saat terjadi kecelakaan, 6 orang tersebut mengatakan jika tidak memahami dengan benar cara melakukan 
pertolongan pertama korban kecelakaan.

\section{METODE PENELITIAN}

Jenis penelitian kuantitatif, dengan menggunankan rancangan penelitian yaitu rancangan praeksperimen (pra-experiment design) yang dilakukan dengan pratestpostest kelompok tunggal (one group pratest posttest). Populasi dalam penelitian ini adalah seluruh ojek baik ojek pangkalan ataupun ojek online yang berjumlah 178 orang. Tempat penelitian ini dilakukan di Desa Bumisari. Teknik sampling penelitian ini adalah purposive sampling. Analisa data univariat dan bivariat menggunakan uji t-tes dependen. Peneliti mendapatkan izin komite etik penelitian dari Universitas Malahayati dengan nomor: 1773 EC/KEP-UNMAL/V/2021 pada tanggal 07 Juni 2021. Alat ukur/Instrumen ini berupa kuesioner. Peneliti menggunakan kuesioner yang sudah pernah dilakukan uji validitas dan reliabilitas, sehingga peneliti tidak melakukan uji validitas dan reliabilitas lagi. Instrument yang digunakan merupakan instrument dari penelitian: Ulfah (2018) Analisis Faktor Yang Mempengaruhi Intensi Masyarakat Terhadap Bantuan Hidup Dasar (BHD) Pada Korban Kecelakaan Lalu Lintas Berdasarkan Theory of Planned Behavior (TPB) dan Hidayah (2017) Pengaruh Pelatihan Bantuan Hidup Dasar Terhadap Tingkat Motivasi Menolong Korban Kecelakaan Lalu Lintas Pada Polisi Kota Yoyakarta. Penelitian ini peneliti menggunakan uji normalitas komologorov smirnov tes dengan ketentuan : Jika nilaip-value $>0,05$ maka distribusi normal Jika nilaipvalue < 0,05 maka distribusi tidak normal, $p$-value pada pengetahuan dan motivasi pretes dengan nilai $p$ value 0,182 dan 0,152 >0,05 dan pada pengetahuan dan motivasi postes dengan nilai $p$-value 0,245 dan $0,167>0,05$ maka data berdistribusi normal dan selanjutnya dapat dilakukan uji t-tes. Aplikasi yang digunakan dalam pengolahan data yaitu aplikasi SPSS ibm versi 26 .

HASIL PENELITIAN DAN PEMBAHASAN

Karakteristik Demografi Responden

Karakteristik Tukang Ojek Di Desa Bumisari Kecamatan Natar Tahun 2021

\begin{tabular}{lcc}
\hline \multicolumn{1}{c}{ Karakteristik } & Frekuensi & Presentase (\%) \\
\hline Usia: & & \\
a. Ojek Pangkalan & 2 & 13,3 \\
- 17-25 (tahun) & 4 & 26,7 \\
- 26-35 (tahun) & 9 & 60,0 \\
- 36-45 (tahun) & 5 & 33,3 \\
b. Ojek Online & 4 & 26,7 \\
- 17-25 (tahun) & 6 & 40,0 \\
- 26-35 (tahun) & & \\
- 36-45 (tahun) & 30 & 100,0 \\
\hline Jenis Kelamin & 0 & \\
Laki-laki & & \\
Perempuan & 2 & 13,3 \\
\hline Pendiddikan: & 6 & 40,0 \\
a. Ojek Pangkalan & 7 & 46,7 \\
- SD & & \\
- SMP & 15 & 100,0 \\
- SMA & & \\
b. Ojek Online & & \\
- SMA & & \\
\hline
\end{tabular}


Lama Bekerja:

a. Ojek Pangkalan

b. Ojek Online

15

$15-50,0$
Berdasarkan tabel menunjukkan bahwa usia pada ojek pangkalan 17-25 tahun berjumlah 2 orang $(13,3 \%)$, usia $26-35$ tahun berjumlah 4 orang $(26,7 \%)$, usia 36 45 tahun berjumlah 9 orang $(60,0 \%)$. Sedangkan usia pada ojek online 1725 tahun berjumlah 5 orang $(33,3 \%)$, usia 26-35 tahun berjumlah 4 orang $(26,7 \%)$, usia $36-45$ tahun berjumlah 6 orang $(40,0 \%)$. Jenis kelamin laki- laki berjumlah 30 orang (100,0\%). Pendidikan pada ojek pangkalan SD berjumlah 2 orang $(13,3 \%)$, SMP berjumlah 6 orang $(40,0 \%)$, SMA berjumlah 7 orang $(46,7 \%)$. Sedangkan pendidikan pada ojek online SMA berjumlah 15 orang $(100,0 \%)$. Lama bekerja pada ojek pangkalan berjumlah 15 orang $(50,0 \%)$, dan lama bekerja pada ojek online berjumlah 15 orang $(50,0 \%)$

\section{Analisis Univariat}

Rata-Rata Pengetahuan Dan Motivasi Sebelum Dan Sesudah Diberi Simulasi Pelatihan Bantuan Hidup Dasar (BHD) Tentang Penanganan Kejadian Kecelakaan Lalu Lintas (KLL) Pada Tukang Ojek Di Desa Bumisari Kecamatan Natar Tahun 2021

\begin{tabular}{lccc}
\hline \multicolumn{1}{c}{ Variabel } & Frekuensi & Mean \pm SD & Min - Maks \\
\hline $\begin{array}{l}\text { Pengetahuan Ojek Pangkalan } \\
\text { Pretest }\end{array}$ & 15 & $4,13 \pm 0,834$ & $3-5$ \\
Posttest & 15 & $8,93 \pm 0,779$ & $8-10$ \\
\hline $\begin{array}{l}\text { Motivasi Ojek Pangkalan } \\
\text { Pretest }\end{array}$ & 15 & $30,67 \pm 2,690$ & $26-34$ \\
Posttest & 15 & $60,00 \pm 10,205$ & $43-70$ \\
\hline $\begin{array}{l}\text { Pengetahuan Ojek Online } \\
\text { Pretest }\end{array}$ & 15 & $3,93 \pm 1,100$ & \\
Posttest & 15 & $8,73 \pm 1,033$ & $7-6$ \\
\hline Motivasi Ojek Online & & & \\
Pretest & 15 & $29,40 \pm 2,131$ & $26-32$ \\
Posttest & 15 & $66,53 \pm 5,592$ & $56-70$ \\
\hline
\end{tabular}

\section{Berdasarkan tabel diatas adalah diketahui bahwa} pengetahuan sebelum diberikan pelatihan Bantuan Hidup Dasar (BHD) berjumlah 15 dengan rata-rata tingkat pengetahuan dari ojek pangkalan adalah $4,13 \pm 0,834$ hal ini berarti bahwa nilai rata-rata pengetahuan ojek pangkalan adalah kurang, dengan nilai terendah adalah 3 dan nilai tertinggi adalah 5 . Pengetahuan sesudah diberikan pelatihan Bantuan Hidup Dasar (BHD) berjumlah 15 mengalami peningkatan dengan nilai rata-rata $8,93 \pm 0,779$ dan ini dikategorikan baik, dengan nilai terendah adalah 8 dan nilai tertinggi adalah 10.
Diketahui bahwa motivasi sebelum diberikan pelatihan Bantuan Hidup Dasar (BHD) berjumlah 15 dengan rata-rata tingkat motivasi dari ojek pangkalan adalah $30,67 \pm 2,690$ hal ini berarti bahwa nilai rata-rata motivasi ojek pangkalan adalah kurang, dengan nilai terendah adalah 26 dan nilai tertinggi adalah 34. Motivasi sesudah diberikan pelatihan Bantuan Hidup Dasar (BHD) berjumlah 15 mengalami peningkatan dengan nilai rata-rata $60,00 \pm 10,205$ dan ini dikategorikan baik, dengan nilai terendah adalah 43 dan nilai tertinggi adalah 70 .

Diketahui bahwa pengetahuan sebelum diberikan pelatihan 
Bantuan Hidup Dasar (BHD) berjumlah 15 dengan rata-rata tingkat pengetahuan dari ojek online adalah $3,93 \pm 1,100$ hal ini berarti bahwa nilai rata-rata pengetahuan ojek online adalah kurang, dengan nilai terendah adalah 2 dan nilai tertinggi adalah 6 . Pengetahuan sesudah diberikan pelatihan Bantuan Hidup Dasar (BHD) berjumlah 15 mengalami peningkatan dengan nilai rata-rata $8,73 \pm 1,033$ dan ini dikategorikan baik, dengan nilai terendah adalah 7 dan nilai tertinggi adalah 10. Diketahui bahwa motivasi sebelum diberikan pelatihan
Bantuan Hidup Dasar (BHD) berjumlah 15 dengan rata-rata tingkat motivasi dari ojek online adalah 29,40 $\pm 2,131$ hal ini berarti bahwa nilai rata-rata motivasi ojek online adalah kurang, dengan nilai terendah adalah 26 dan nilai tertinggi adalah 32. Motivasi sesudah diberikan pelatihan Bantuan Hidup Dasar (BHD) berjumlah 15 mengalami peningkatan dengan nilai rata-rata $66,53 \pm 5,592$ dan ini dikategorikan baik, dengan nilai terendah adalah 56 dan nilai tertinggi adalah 70 .

Analisis Bivariat

Efektivitas Simulasi Pelatihan Bantuan Hidup Dasar (BHD) Terhadap Peningkatan Pengetahuan Dan Motivasi Tentang Penanganan Kejadian Kecelakaan Lalu Lintas (KLL) Pada Tukang Ojek Di Desa Bumisari Kecamatan Natar Tahun 2021

\begin{tabular}{|c|c|c|c|c|}
\hline Variabel & Mean \pm SD & $t$ & p-value & OR \\
\hline $\begin{array}{l}\text { Pengetahua Ojek } \\
\text { Pangkalan } \\
\text { Pretest } \\
\text { Posttest }\end{array}$ & $4,800 \pm 1,320$ & 14,082 & $0,000^{*}$ & $5,531-4,069$ \\
\hline $\begin{array}{l}\text { Motivasi Ojek Pangkalan } \\
\text { Pretest } \\
\text { Posttest }\end{array}$ & $29,333 \pm 9,708$ & 11,703 & $0,000^{*}$ & $34,709-23,957$ \\
\hline $\begin{array}{l}\text { Pengetahuan Ojek Online } \\
\text { Pretest } \\
\text { Posttest }\end{array}$ & $4,800 \pm 1,521$ & 12,220 & $0,000^{*}$ & $5,642-3,958$ \\
\hline $\begin{array}{l}\text { Motivasi Ojek Online } \\
\text { Pretest } \\
\text { Posttest }\end{array}$ & $37,133 \pm 6,174$ & 23,292 & $0,000^{*}$ & $40,553-33,714$ \\
\hline
\end{tabular}

Berdasarkan table diatas terdapat nilai rata-rata tingkat pengetahuan (pretest dan posttest) ojek pangkalan yaitu $4,800 \pm 1,320$ dengan $p$-value sebesar $0,000(<0,5)$. Hal ini menunjukkan terdapat pengaruh pelatihan Bantuan Hidup Dasar terhadap efektivitas simulasi pelatihan bantuan hidup dasar (BHD) terhadap peningkatan pengetahuan tentang penanganan kejadian kecelakaan lalu lintas (KLL) pada tukang ojek pangkalan di Desa Bumisari Kecamatan Natar Tahun 2021. Nilai rata-rata tingkat motivasi (pretest dan posttest) ojek pangkalan yaitu 29,333 $\pm 9,708$ dengan $\mathrm{p}$-value sebesar $0,000(<0,5)$ maka hal ini menunjukkan terapat pengaruh pelatihan Bantuan Hidup Dasar (BHD) terhadap efektivitas simulasi pelatihan bantuan hidup dasar (BHD) terhadap peningkatan motivasi tentang penanganan kejadian kecelakaan lalu lintas (KLL) pada tukang ojek pangkalan di Desa Bumisari Kecamatan Natar Tahun 2021.

Terdapat nilai rata-rata tingkat pengetahuan (pretest dan 
posttest) ojek online yaitu $4,800 \pm 1,521$ dengan $p$-value sebesar $0,000(<0,5)$. Hal ini menunjukkan terdapat pengaruh pelatihan Bantuan Hidup Dasar terhadap efektivitas simulasi pelatihan bantuan hidup dasar (BHD) terhadap peningkatan pengetahuan tentang penanganan kejadian kecelakaan lalu lintas (KLL) pada tukang ojek online di Desa Bumisari Kecamatan Natar Tahun 2021. Nilai rata-rata tingkat motivasi (pretest dan

\section{Pembahasan}

\section{Karakteristik Responden}

Jumlah sampel penelitian ini adalah 30 responden. Hasilnya menunjukkan usia responden sebagian besar adalah berada pada dewasa akhir (36-45 tahun) sebanyak 9 responden $(60,0 \%)$ dan sebagian kecil berada pada remaja akhir (1725 tahun) sebanyak 2 responden $(13,3 \%)$. Hasil penelitian ini sejalan dengan Hidayah (2017), bahwa usia dewasa akhir mendominasi pekerja pada profesi tukang ojek di Kota Salatiga yang mana profesi tersebut menjadi sesuatu pekerjaan untuk para pensiunan yang sudah tidak dapat melakukan pekerjaan lainnya. Berdasarkan karakteristik pendidikan pada ojek pangkalan terbanyak adalah Sekolah Menengah Atas (SMA) sebanyak 7 responden $(46,7 \%)$, pendidikan pada ojek online terbanyak adalah Sekolah Menengah Atas (SMA) sebanyak 15 responden $(100,0 \%)$, seluruh responden $(100,0 \%)$ berjenis kelamin laki-laki. Penelitian ini sesuai dengan penelitiaan Hidayah (2017) bahwa laki-laki lebih dominan pada profesi jasa transportasi karena laki-laki merupkan tulang punggung keluarga serta pekerjaan dalam bidang transportasi memang secara wajar dilakukan oleh seorang laki-laki dikarenakan pekerjaan tersebut mengandung banyak resiko seperti tindakan kriminalitas. posttest) ojek online yaitu $37,133 \pm 6,174$ dengan p-value sebesar $0,000 \quad(<0,5)$ maka hal ini menunjukkan terapat pengaruh pelatihan Bantuan Hidup Dasar (BHD) terhadap efektivitas simulasi pelatihan bantuan hidup dasar (BHD) terhadap peningkatan motivasi tentang penanganan kejadian kecelakaan lalu lintas (KLL) pada tukang ojek online di Desa Bumisari Kecamatan Natar Tahun 2021.

Karakteristik lama bekerja pada ojek pangkalan terbanyak adalah rata-rata $3,14 \pm 1,125$ yang artinya lama bekerja pada ojek pangkalan adalah 3 tahun, lama bekerja pada ojek online terbanyak adalah rata-rata $2,87 \pm 0,915$ yang artinya lama bekerja pada ojek online adalah 2 tahun. Berdasarkan karakteristik lama bekerja pada ojek pangkalan terbanyak adalah adalah 3 tahun, lama bekerja pada ojek online terbanyak adalah 2 tahun. Hasil penelitian ini sejalan dengan Efendi \& Makhfudli (2013). Menunjukkan sebagian besar responden memiliki pengalaman kerja sebagai tukang ojek. Pengalaman yang lebih lama akan menambah pengetahuan dan ketrampilan profesional serta mengembangkan kemampuan dalam mengambil sebuah keputusan.

\section{Analisis Univariat}

Pengetahuan Sebelum Dan Sesudah Diberi Simulasi Pelatihan Bantuan Hidup Dasar (BHD) Tentang Penanganan Kejadian Kecelakaan Lalu Lintas (KLL) Pada Tukang Ojek Di Desa Bumisari Kecamatan Natar Tahun 2021

Pada table menunjukkan bahwa nilai maksimal dan minimal pada pengetahuan ojek pangkalan 3 - 5, serta ojek online 2 - 6. Dari 10 
pertanyaan kuesioner tentang pengetahuan BHD yang memiliki rata-rata skor rendah oleh responden yaitu pertanyaan nomor 1 pada pretes postes kelompok ojek pangkalan, pertanyaan nomor 1 berupa pertanyaan BHD merupakan pertolongan pertama pada korban kecelakaan lalu lintas. Hal ini disebabkan karena responden sebelumnya belum pernah mengetahui tentang definisi BHD dan seperti apa BHD prosedur penanganannya diterapkan saat terjadinya kecelakaan lalu lintas.

Sedangkan pada kelompok ojek online, pertanyaan nomor 1 dan 5 memiliki nilai terendah pada pretes sedangkan pada pengukuran postes nomor 1 dan 10 memiliki nilai terendah. Pertanyaan nomor 1 berupa pertanyaan BHD merupakan pertolongan pertama pada korban kecelakaan lalu lintas, dan pada pertanyaan nomor 10 merupakan pertanyaan yang berisi inisitif untuk memposisikan korban apabila telah menunjukan tanda-tanda perbaikan. Berdasarkan pertanyaan nomor 1 hal ini senada dengan kelompok ojek pangkalan yaitu kurangnya informasi yang diterima, sedangkan untuk nomor 10 responden tidak memiliki basic/pelatihan untuk menolong korban kecelakaan, sehingga tidak memhami cara memposisikan korban yang baik dan benar sehingga tidak menimbulkan cedera lainnya, seperti kesalahan dalam melakukan pertolongan pertama.

Sejalan dengan penelitian Basri., Istihora (2019) Pelatihan Bantuan Hidup Dasar (BHD) Meningkatkan Pengetahuan Dan Kesiapan Menolong Korbankecelakaan Pada Tukang Ojek. Sebagian besar responden mempunyai pengetahuan kurang $(61,9 \%)$, yang mempunyai pengetahuan cukup sebanyak $(38,1 \%)$ dan tidak ada responden yang mempunyai pengetahuan baik.
Sesudah diberikan pelatihan adalah 8 responden berpengetahuan baik $(38,1 \%), \quad 7$ responden dengan pengetahuan cukup (33,3\%) dan 6 responden dengan pengetahuan kurang $(28,6 \%)$.

Sejalan dengan teori yang dikemukakan oleh Budiman., Riyanto (2013) Informasi yang diperoleh baik dari pendidikan formal maupun nonformal dapat memberikan pengaruh jangka pendek (immediate impact) sehingga menghasilkan perubahan atau peningkatan pengetahuan. Berkembangnya teknologi akan menyediakan bermacam-macam media massa yang dapat mempengaruhi pengetahuan masyarakat tentang inovasi baru. Dalam penyampaian informasi sebagai tugas pokoknya, media massa juga membawa pesan-pesan yang berisi sugesti yang dapat mengarahkan opini seseorang. Adanya informasi baru mengenai suatu hal memberikan landasan kognitif baru bagi terbentukanya pengetahuan terhadap hal tersebut.

Menurut peneliti pemberian pelatihan BHD pada ojek baik pangkalan ataupun online memberikan pengaruh positif bagi mereka, salah satunya adalah meningkatnya pengetahuan responden dalam melakukan pertolongan pertama pada korban kecelakaan dengan baik dan benar, sehingga tidak menimbulkan cidera akibat salahnya penanganan saat menunggu ambulance ataupun tim medis.

Motivasi Sebelum Dan Sesudah Diberi Simulasi Pelatihan Bantuan Hidup Dasar (BHD) Tentang Penanganan Kejadian Kecelakaan Lalu Lintas (KLL) Pada Tukang Ojek Di Desa Bumisari Kecamatan Natar Tahun 2021

Pada table menunjukkan bahwa nilai maksimal dan minimal pada 
pengetahuan ojek pangkalan 3-5, serta ojek online 2-6. Dari 20 pertanyaan kuesioner tentang motivasi BHD yang memiliki ratarata skor rendah oleh responden ojek pangkalan pretes yaitu pertanyaan nomor 3 dan 20, dimana ke dua pertanyaan tersebut kesediaan menolong korban, hanya saja pada nomor 3 pertanyaan bernada negatif yaitu "saya hanya akan menolong korban kecelakaan ketika tidak ada orang dilokasi" yang artinya kesadaran dan motivasiu responden sangat kurang, hal ini dapat disebabkan karena responden takut disalahkan atau takut saat dijadikan saksi dalam gelar tempat kejadian perkara (TKP) oleh penegak hukum.

Setelah diberikan penyuluhan terhadap responden motivasi pada kelompok ojek pangkalan mengalami peningkatan skor dan hanya 1 skor pada soal nomor 2 yang memiliki skor terendah, dengan pertanyaan ketersediaan menolong korban kecelakaan apabila banyak orang dilokasi kejadian. Hal ini masih senada dengan pernyataan diatas, motivasi menolong dalam hal ini dipengaruhi oleh imbas atau efek yang akan diterima oleh responden nantinya, sehingga meskipun telah diberikan pelatihan, responden tetap harus hati-hati dan tidak ingin menjadi orang yang disalahkan ataupun dijadikan saksi, karena mungkin saja dapat menyita waktu responden.

Pada kelompok ojek online rata-rata skor pertanyaan pretes terendah berada pada nomor 16 dengan pernyataan responden tidak akan menolong korban kecelakaan ketika sedang sedih, hal ini menunjukkan jika, perilaku dan motivasi dipengaruhi oleh perasaan seseorang saat ini, sedangkan setelah diberi pelatihan skor terendah postes berada pada nomor 17 yang menyatakan responden akan sukarela apabila ada perintah untuk memberikan pertolongan pertama pada korban kecelakaan

Sejalan dengan penelitian yang dilakukan oleh Hidayah (2017) Pengaruh Pelatihan Bantuan Hidup Dasar Terhadap Tingkat Motivasi Menolong Korban Kecelakaan Lalu Lintas Pada Polisi Kota Yoyakarta. Hasil yang didapat pada penelitian ini rata-rata pada sebelum dan sesudah diberikan pelatihan tidak mengalami perubahan yang signifikan dengan nilai mean 65,37 dan setelah diberi pelatihan 65,66 .

Menurut Mc. Donald dalam Sadirman (2011), motivasi adalah perubahan energy dalam diri seseorang yang ditandai dengan munculnya "feeling" dan didahului dengan tanggapan terhadap adanya tujuan. Dari pengertian yang dikemukakan Mc. Donald ini mengandung tiga elemen penting yaitu 1. Bahwa motivasi mengawali terjadinya perubahan energi pada diri setiap individu manusia. 2 motivasi ditandai dengan munculnya, rasa/ feeling, afeksi seseorang. Dalam hal ini motivasi relavan dengan persoalan kejiwaan, afeksi dan emosi yang dapat menentukan tingkah laku manusia, 3 motivasi akan dirangsang karena adanya tujuan, jadi motivasi dalam hal ini sebenarnya merupakan respon dari suatu aksi, yakni tujuan.

Menurut peneliti Peningkatan motivasi menolong korban kecelakaan lalu lintas pada kelompok intervensi juga dipengaruhi oleh cara fasilitator dalam memberikan atau menyampaikan isi materi pelatihan Bantuan Hidup Dasar (BHD) kepada responden. Penyampaian harus menggunakan bahasa yang lugas dan mudah dimengerti, yang akan berdampak pada meningkatnya pengetahuan dan juga motivasi responden untuk memberikan pertolongan pertama pada korban kecelakaan. 
Analisis Bivariat

Efektivitas Simulasi Pelatihan
Bantuan Hidup Dasar (BHD)
Terhadap
Pengetahuan Dan Motivasi Tentang
Penanganan Kejadian Kecelakaan
Lalu Lintas (KLL) Pada Tukang Ojek
Di Desa Bumisari Kecamatan Natar
Tahun 2021
bahwa nilai rata-rata pengetahuan sebelum dan sesudah diberi simulasi pelatihan bantuan hidup dasar (BHD) tentang penanganan kejadian kecelakaan lalu lintas (KLL) pada tukang ojek pangkalan di Desa Bumisari Kecamatan Natar Tahun 2021 dengan mean 4,800 dan terdapat nilai rata-rata motivasi sebelum dan sesudah diberi simulasi pelatihan BHD yaitu 29,333. Adapun nilai rata-rata pengetahuan sebelum dan sesudah diberi simulasi pelatihan bantuan hidup dasar (BHD) tentang penanganan kejadian kecelakaan lalu lintas (KLL) pada tukang ojek online di Desa Bumisari Kecamatan Natar Tahun 2021 dengan mean 4,800 dan terdapat nilai ratarata motivasi sebelum dan sesudah diberi simulasi pelatihan BHD yaitu 37,133.

Hasil analisa data bivariat menggunakan uji t-tes didapat nilai p-value $0,000<0,05$ maka dapat disimpulkan bahwa terdapat efektivitas simulasi pelatihan bantuan hidup dasar (BHD) terhadap peningkatan pengetahuan dan motivasi tentang penanganan kejadian kecelakaan lalu lintas (KLL) pada tukang ojek di Desa Bumisari Kecamatan Natar Tahun 2021.

Hal ini sejalan dengan penelitian yang dilakukan oleh Istihora., Basri (2019) dengan judul Pelatihan Bantuan Hidup Dasar (BHD) Meningkatkan Pengetahuan Dan Kesiapan Menolong Korban Kecelakaan Pada Tukang Ojek. Hasil uji statistik Wilcoxon Signed Rank
Test menunjukkan ada perbedaan tingkat pengetahuan dan tingkat kesiapan menolong setelah diberikan pelatihan BHD dengan nilai $p=0,002$ untuk tingkat pengetahuan dan $\mathrm{p}=0,000$ untuk tingkat kesiapan menolong.

Menurut peneliti pengetahuan mempunyai beberapa tingkatan yaitu tahu dimana seseorang dapat mengingat semua materi yang telah dipelajari sebelumnya, memahami yaitu kemampuan menjelaskan secara benar tentang obyek yang diketahui dan dapat menginterpretasikan materi tersebut secara benar, aplikasi yaitu kemampuan menggunakan materi yang telah dipelajari pada kondisi dan situasi.

Sejalan dengan pendapat yang dikemukakan oleh Nasrul (1998; Ahmad Hasan Basri, 2019) Pengetahuan tentang BHD akan meningkatkan pengetahuan individu tentang mengidentifikasi tandatanda korban yang harus diberikan BHD, cara-cara melakukan tahapan BHD dan juga mengetahui tandatanda korban yang telah dalam keadaan pulih atau tidak terselamatkan. Pengetahuan tentang BHD ini tentunya dapat mengurangi kematian. Pengetahuan yang diperoleh akan berkaitan dengan stimulus yang dapat meningkatkan motivasi seseorang, dan akan berimbas pada perubahan perilaku seseorang. Peningkatan pengetahuan responden juga dipengaruhi oleh metode pelatihan yang diberikan yaitu melalui demonstrasi dan tanya jawab, keberhasilan pendidikan kesehatan dipengaruhi oleh alat bantu yang dapat mempermudah pemahaman sasaran. Demonstrasi tindakan BHD akan membantu responden dalam mengingat kembali materi yang telah diberikan.

Pelatihan adalah sebuah proses mengajarkan pengetahuan dan 
keahlian tertentu serta sikap agar seseorang semakin terampil dan mampu melaksanakan tanggung jawab dengan semakin baik, sesuai dengan standar. Materi yang disampaikan dalam pelatihan akan menjadi pesan atau informasi yang diterima oleh peserta, informasi diperoleh dari data yang sudah diolah sehingga mempunyai arti. Kemudian data ini akan disimpan dalam neuron-neuron (menjadi memori) di otaknya. Informasi yang sudah tersimpan ini akan saling terhubung dengan masalah yang dihadapi oleh manusia dan tersusun secara sistematik sehingga memiliki model untuk memahami atau memiliki pengetahuan yang terkait dengan masalah tersebut menurut Mangkuprawira, (2013)

Sejalan dengan pendapat yang dikemukakan oleh Notoatmodjo (2003; Nursalam, 2018) Pengetahuan merupakan hasil dari "Tahu" dan ini terjadi setelah orang melakukan penginderaan terhadap suatu objek tertentu. Penginderaan terjadi melalui panca indra manusia, yaitu indra penglihatan, pendengaran, penciuman, rasa dan raba. Sebagian besar pengetahuan manusia diperoleh melalui mata dan telinga, yaitu proses melihat dan mendengar. Selain itu melalui mata dan telinga yaitu proses melihat dan mendengar, selanjutnya proses pengalaman dan proses belajar dalam pendidikan formal maupun informal.

Faktor yang mempengaruhi motivasi yaitu kemampuan dan pengetahuan tentang pekerjaan sehingga tukang ojek (pangkalan/online) ketika belum mempunyai pengetahuan tentang Bantuan Hidup Dasar (BHD) maka berdampak pada kemampuan dalam melakukan Bantuan Hidup Dasar (BHD) Menurut Ardana, (2008). Pengetahuan tentang BHD akan meningkatkan pengetahuan individu tentang mengidentifikasi tanda- tanda korban yang harus diberikan $\mathrm{BHD}$, cara-cara melakukan tahapan BHD dan juga mengetahui tandatanda korban yang telah dalam keadaan pulih atau tidak terselamatkan. Pengetahuan tentang BHD ini tentunya dapat mengurangi kematian. Pengetahuan yang diperoleh akan berkaitan dengan stimulus yang dapat meningkatkan motivasi seseorang, dan akan berimbas pada perubahan perilaku seseorang. Hal tersebut berdampak pada motivasi tukang ojek dalam melakukan BHD pada korban kecelakaan lalu lintas. Terjadinya peningkatan rata-rata motivasi pada responden (ojek online dan ojek pangkalan) akan menuntun seseorang untuk cenderung berperilaku psikososial dan berlaku sebaliknya. Hal yang baik ini dapat dipelihara dan ditingkatkan pada aspek yang dapat diubah yaitu lingkungan yang kondusif kearah perilaku positif. Sedangkan untuk motivasi yang lebih bersifat mengharapkan timbal balik sebenarnya juga dapat dilatih untuk kearah yang positif juga dengan cara memodifikasi lingkungan terutama lingkungan dalam keluarga sebagai sarana pendidikan pertama (Notoadmodjo, 2012).

Hal ini sejalan dengan pendapat yang dikemukakan oleh Soekanto (2002; Budiman., Ariyanto, 2013) Pengetahuan merupakan domain yang penting dalam membentuk tindakan seseorang (overt behavior). Proses kognitif meliputi ingatan, pikiran, persepsi, simbol-simbol penalaran dan pemecahan persoalan. Penegertian dalam kamus besar Bahasa Indonesia (2015), diartikan segala sesuatu yang diketahui atau segala sesuatu yang berkenaan dengan hal mata pelajaran. Kategori pengetahuan meliputi kemampuan untuk mengatakan kembali dari ingatan hal-hal khusus dan umum, metode 
dan proses atau mengingat suatu pola, susunan, gejala atau peristiwa. Mc. Donald dalam Sadirman (2011), motivasi adalah perubahan energy dalam diri seseorang yang ditandai dengan munculnya "feeling" dan didahului dengan tanggapan terhadap adanya tujuan.

\section{Kesimpulan}

1. Karakteristik usia ojek pangkalan dengan rata-rata $37,13 \pm 7.140$ pada usia 36-45 tahun adalah sebanyak 9 responden $(60,0 \%)$, karakteristik usia ojek online dengan rata-rata $30,67 \pm 7,997$ pada usia 36-45 tahun adalah sebanyak 6 responden (40,0\%), karakteristik berdasarkan jenis kelamin terbanyak adalah lakilaki sebanyak 30 responden $(100,0 \%)$, berdasarkan karakteristik pendidikan pada ojek pangkalan terbanyak adalah Sekolah Menengah Atas (SMA) sebanyak 7 responden $(46,7 \%)$, pendidikan pada ojek online terbanyak adalah Sekolah Menengah Atas (SMA) sebanyak 15 respnden $(100,0 \%)$, berdasarkan karakteristik lama bekerja pada ojek pangkalan terbanyak adalah rata-rata $3,14 \pm 1,125$ yang artinya lama bekerja pada ojek pangkalan adalah 3 tahun, lama bekerja pada ojek online terbanyak adalah rata-rata $2,87 \pm 0,915$ yang artinya lama bekerja pada ojek online adalah 2 tahun.

2. Hasil analisa data bivariat menggunakan uji dependen $t$-tes didapat nilai $p$-value $0,000<0,05$ maka dapat ditarik kesimpulan bahwa terdapat efektivitas simulasi pelatihan bantuan hidup dasar (BHD) terhadap peningkatan pengetahuan dan motivasi tentang penanganan kejadian kecelakaan lalu lintas (KLL) pada tukang ojek di Desa
Bumisari Kecamatan Natar Tahun 2021.

\section{Saran}

Bagi Peneliti Selanjutnya

Diharapkan hasil penelitian ini dapat dijadikan referensi untuk penelitian selanjutnya dengan menambah variabel lainnya seperti variabel dependen dan independen. Sampelnya lebih beragam dengan melibatkan ojek online dan berbagai provider (Gojek, Grab, Maxim, dan lain sebagainya) serta melibatkan perusahaan Taxi mobil.

\section{DAFTAR PUSTAKA}

AHA. (2015). Resusitasi Jantung Paru. AHA Guildines.

Amajida, F. D. (2016). Kreativitas digital dalam masyarakat risiko perkotaan: Studi tentang ojek online "Go-Jek" di Jakarta. Informasi, 46(1), 115-128.

Ardana, P., Wiharta, D. M., \& Maia, F. N. D. R. (2008). Kunci pintu otomatis menggunakan aplikasi RFID card. Jurnal Teknologi Elektro Vol. 7 No. 2, Desember 2008.

Arifain, S. M. K., Yusof, F., Aziz, S. Suhaini, N., \& Suhaini, N. (2021). The Influence of Social Support on Marriage Satisfaction among Working Women in Selangor, Negeri Sembilan And Melaka.

Azwar, Saifudin. (2016). Sikap Manusia Teori Dan Pengukurannya.

Yogyakarta: Pustaka Belajar.

Budiman \& Riyanto. (2013). Pengukuran Sikap dan Pengetahuan. Salemba Medika: Jakarta. 
Dahlan, A., \& Syahminan, T. V. (2017). Pengaruh terapi kompres hangat terhadap nyeri haid (Dismenorea) pada siswi smk perbankan simpang haru padang. Jurnal Endurance: Kajian Ilmiah Problema Kesehatan, 2(1), 37-44.

Dirlantas Polda Lampung. (2019). Data Kecelakaan di Provinsi Lampung.

Efendi F \& Makhfudli (2013). Keperawatan Kesehatan Komunitas. Jakarta: Salemba Medika.

Firdaus, A. D., Agoes, A., \& Lestari, R. (2018). Analisis FaktorFaktor Yang Mempengaruhi Kemauan Orang Awam Untuk Memberikan Pertolongan Pertama Pada Korban Kecelakaan Lalu Lintas Di Kota Malang. Journal of Nursing Care and Biomoleculer, 3(2), 128-134.

Gigy, D. P. D., Setyobudi, A., \& Tira, D. S. (2020). Faktor-Faktor Yang Berhubungan Dengan Risiko Kecelakaan Lalu Lintas Pada Siswa Sekolah Menangah Atas (Sma) Di Kota Kupang Tahun 2019: (Studi kasus pada Sekolah Menengah Atas Negeri 3 dan 7 serta Sekolah Menengah Kejuruan Negeri 2 Kota Kupang). Jurnal Pangan Gizi dan Kesehatan, 9(2), 1091-1099.

Harapan, H., Mudatsir, M., Yufika, A., Nawawi, Y., Wahyuniati, N., Anwar, S., ... \& Imrie, A. (2019). Community acceptance and willingnessto-pay for a hypothetical Zika vaccine: A cross-sectional study Indonesia. Vaccine, 37(11), 1398-1406.

Hidayah (2017) Pengaruh Pelatihan Bantuan Hidup Dasar Terhadap Tingkat Motivasi
Menolong Korban Kecelakaan Lalu Lintas Pada Polisi Kota Yoyakarta. Universitas Muhammadiyah: Yogyakarta.

Irfani, Q. I. (2019). Bantuan Hidup Dasar. Cermin Kedokteran, 46(6), 458-461. Istikharah, R., \& Firmansyah, R. Ningrum, V. D., (2019). Allele Frequency of SLC22A1 Met420del Metformin Main Transporter Encoding Gene among Javanese-Indonesian Population. Open access Macedonian journal of medical sciences, 7(3), 378.

Jasa Raharja. (2019). https://www.jasaraharja.co. id/layanan/jumlah-santunan

Kepolisian Resor Lampung Selatan. (2020). Data Kecelakaan di Kabupaten Lampung Selatan.

Manampiring, A. E, Tanriono, Y., Doda, D. V. (2019). Hubungan Kelelahan Kerja, Kualitas Tidur, Perilaku Pengemudi, dan Status Gizi dengan Kecelakaan Kerja pada Pengemudi Ojek di Kota Bitung. KESMAS, 8(6).

Mangkuprawira, Sjafri. 2007. Manajemen Mutu Sumber Daya Manusia. Bogor : Ghalia Indonesia

Muniarti, S. (2019). Pengaruh Simulasi Pelatihan Bantuan Hidup Dasar (Bhd) Terhadap Motivasi Dan Skill Resusitasi Jantung Paru (RJP) Pada Karang Taruna Rw 06 Kampung Utan Kelurahan Krukut Depok (Doctoral dissertation, Universitas Pembangunan Nasional Veteran Jakarta).

Mutmainah, S. A., Abi, A. Y., Fadila, V. D., \& Fauzi, Y. N. (2019). Formulasi Gel Mukus Ikan Sidat (Anguilla Bicolor) Sebagai Kandidat Penyembuh Luka Bakar. Pharmaqueous: 
Jurnal Ilmiah

Kefarmasian, 1(1), 106-112.

Ngalim Purwanto. (2007). Psikologi Pendidikan, Bandung: PT Remaja Rosdakarya.

Ngirarung, Mulyadi, \& Malara. (2017; Watung, G. I. V. 2021). Edukasi Pengetahun dan Pelatihan Bantuan Hidup Dasar Pada Siswa Remaja SMA Negeri

Kotamobagu. Community Engagement and Emergence Journal (CEEJ), 2(1), 21-27.

Notoadmodjo, S. (2014). Pendidikan dan Prilaku Kesehatan, Jakarta: Rineka Cipta.

Notoadmodjo. (2012). Promosi Kesehatan Dan Prilaku Kesehatan. Jakarta: Rineka Cipta.

Notoadmodjo. (2018). Metodologi Riset Keperawatan. Jakarta: Rineka Cipta.

Notoadmodjo. (2018). Promosi Kesehatan Dan Prilaku Kesehatan. Jakarta: Rineka Cipta.

Nursalam. (2018). Manajemen Keperawatan; Aplikasi dalam Praktik Keperawatan Profesional. Edisi 3. Jakarta: Salemba Medika.

O'meara, (2012; Pallavisarji, 2013; Firdaus, A. D., Agoes, A., \& Lestari, R. (2018). Analisis Faktor-Faktor Yang Mempengaruhi Kemauan Orang Awam Untuk Memberikan Pertolongan Pertama Pada Korban Kecelakaan Lalu Lintas Di Kota Malang. Journal of Nursing Care and Biomoleculer, 3(2), 128-134.

Putri, H. S., \& Diamantina, A. (2019). Perlindungan Hukum Terhadap Keselamatan Dan Keamanan Pengemudi Ojek Online Untuk Kepentingan Masyarakat. Jurnal
Pembangunan

Hukum Indonesia, 1(3), 392-403.

Rahmadita, S. S. (2019). Pengaruh Pendidikan Kesehatan Dengan Infografis Melalui Media Sosial Terhadap Perilaku Pertolongan Pertama Pada Kecelakaan Di Pengemudi Ojek Online Surabaya (Doctoral

dissertation, Universitas Airlangga).

Setiawati,

D.

0. (2019). Perlindungan Hukum Bagi Penyandang Disabilitas Sebagai Pengemudi Ojek Online (Doctoral Dissertation, Universitas 17 Agustus 1945).

Silalahi, S. L. B., Handayani, P. W., \& Munajat, Q. (2017). Service quality analysis for online transportation services: Case study of GO-JEK. Procedia Computer Science, 124, 487495.

Syah, Muhibbin. (2012). Psikologi Pendidikan, Bandung: PT Remaja Rosdakarya.

Syahriza, M. (2019). Kecelakaan Lalulintas: Perlukah Mendapatkan Perhatian Khusus?. Averrous: Jurnal Kedokteran dan Kesehatan Malikussaleh, 5(2), 89-101.

Tanriono, Y., Doda, D. V., \& Manampiring, A. E. (2019). Hubungan Kelelahan Kerja, Kualitas Tidur, Perilaku Pengemudi, dan Status Gizi dengan Kecelakaan Kerja pada Pengemudi Ojek di Kota Bitung. KESMAS, 8(6).

Uno, B. Hamzah. (2011). Orientasi Baru dalam Psikologi Pembelajaran. Jakarta: PT BumiAksara. 